\title{
Effect of a School-Based Intervention on Nutritional Knowledge and Habits of Low-Socioeconomic School Children in Israel: A Cluster-Randomized Controlled Trial
}

\author{
Vered Kaufman-Shriqui ${ }^{1,2,3}$, Drora Fraser ${ }^{1}$, Michael Friger ${ }^{1}$, Dikla Geva ${ }^{1}$, Natalya Bilenko ${ }^{1}$, \\ Hillel Vardi ${ }^{1}$, Naama Elhadad ${ }^{4}$, Karen Mor ${ }^{4}$, Zvi Feine ${ }^{4}$ and Danit R. Shahar ${ }^{1, *}$ \\ 1 Department of Public Health, Faculty of Health Sciences, Ben-Gurion University of the Negev, POB 653, \\ Beer-Sheva 84105, Israel; veredk@ekmd.huji.ac.il (V.K.-S.); fdrora@bgu.ac.il (D.F.); friger@bgu.ac.il (M.F.); \\ diklah@integristat.com (D.G.); natalya@bgu.ac.il (N.B.); hilel@bgu.ac.il (H.V.) \\ 2 Braun School of Public Health, and Community Medicine, the Hebrew University Hadassah, \\ Jerusalem 91120, Israel \\ 3 Centre for Research on Inner City Health, St. Michael's Hospital, Toronto, ON M5B 1W8, Canada \\ 4 Ashalim: The Association for Planning \& Development of Services for Children and Youth at Risk and \\ Their Families, American Jewish Joint Distribution Committee, POB 3489, Jerusalem 91034, Israel; \\ namanat@gmail.com (N.E.); karenm@jdc.org.il (K.M.); zvif@jdc.org.il (Z.F.) \\ * Correspondence: dshahar@bgu.ac.il; Tel.: +972-5073-48786; Fax: +972-8647-7638
}

Received: 17 February 2016; Accepted: 13 April 2016; Published: 21 April 2016

\begin{abstract}
Early social and economic deprivation, associated with poor nutrition and physical inactivity, may lead to adverse health trajectories. A cluster-randomized controlled-trial examining the effect of a school-based comprehensive intervention on nutrition knowledge, eating habits, and behaviors among low socioeconomic status (LSES) school-aged children was performed. LSES school-aged children (4-7 years) and their mothers were recruited from 11 schools, located in one town. The intervention was implemented on three levels: children, mothers, and teachers. The intervention (IArm) included nutrition classes for children, mothers, and teachers and physical activity (PA) classes for children; the control (CArm) received PA only. Interventions were conducted by professional personnel, who were trained during in a two-day session to deliver the specific program in schools. Family data were obtained by parental interviews. Food knowledge observations, packed lunch records, and anthropometric measurements were obtained in school at baseline, six months, and at the end of the school year. Of 258 children enrolled, 220 (87.6\%) completed the six-month program. Only children in the IArm improved their nutrition knowledge and eating-habits and increased food variety and fruit and vegetable consumption, quality score of packed lunches $(p<0.001$ for all), habitual water drinking increased $(p=0.02)$, and decreased sweet-drink consumption $(p=0.05)$. A school-based comprehensive nutrition intervention targeting LSES population improved eating habits, nutritional knowledge, and healthier packed lunches.
\end{abstract}

Keywords: nutrition; low socioeconomic; childhood obesity; health promotion; pediatric nutrition; preschool children; school-based intervention

\section{Introduction}

The double burdens of obesity and malnutrition are challenging public health issues worldwide, particularly among low socioeconomic status (LSES) children [1,2]. Diets rich in low-nutrient, energy-dense foods combined with sedentary lifestyles result in nutritional deficiencies and concurrent excessive weight gain relative to height increase [3,4]. Poor nutrition in childhood, in turn, is associated with adverse life-course health, chronic diseases, and lower cognitive performances $[5,6]$. In young 
children, a diet high in energy-dense foods leaves little room for nutrient-dense foods, which are crucial for optimal growth and development [7]. Teaching children about healthy nutrition when they are young, therefore, may help prevent the adverse outcomes described above. In addition, the evidence in the literature suggests that diet quality is a more important determinant in the prevention of obesity than is caloric intake [8,9].

Mothers play an important role in the development of children's dietary habits by controlling availability, accessibility, and exposure to food $[10,11]$ in the family. Mothers' and teachers' knowledge and role-modeling of a healthy lifestyle were shown to be associated with activity and healthier food choices of children [12-14]. In addition, nutritional education programs in school settings were shown to concomitantly increase the children's knowledge and decrease the risk for an obesogenic environment in the family $[15,16]$. These findings support common knowledge that health habits and behaviors are established during early childhood and track into adulthood. These include food choice patterns, [17] levels of physical activity, and sedentary behaviors [18]. Although school is a critical period in human development, comprehensive interventions are scarce among children ages five and below who attend school classes, [19] even more so among LSES children [20]. Among the interventions conducted in school settings, some focused on educational components only [21,22] while others examined physical activity (PA) components exclusively; $[23,24]$ only a few were comprehensive $[25,26]$. Most of the interventions showed limited success [14].

Our study examined a comprehensive school-based intervention focused on healthy lifestyle among the understudied population of LSES school children aged four to seven years during a single school year (overall 10 months). Following the ecological model [12] for promoting children's healthy eating, the intervention was implemented among three domains that are considered as influencing children's eating behaviors; (1) the individual level—the children; (2) the familial level—mothers; and (3) the educational level, represented by the school teachers.

Our intervention was designed to enhance children's nutritional knowledge and to promote their mother's adoption of healthy feeding habits, while considering food affordability constraints. Our primary objective was to improve the children's nutritional habits; the secondary objective was to increase participants' nutritional knowledge and levels of physical activity.

\section{Materials and Methods}

\subsection{Study Population and Design}

The cluster-randomized trial was conducted during a single school year in Beer Sheva, a big metropolis in southern Israel. Participants were enrolled during September to November 2008, and the intervention took place over the next three months, followed by a three-month follow up with the trial concluding in June 2009. Eligibility criteria were healthy children, aged 4-7, who were attending LSES school classes to which admission is determined based on household SES according to the local municipality criteria. Exclusion criteria included any chronic disease, developmental problems, attending a weight-control program, or any psychiatric problem of the child or a parent. Schools were eligible as long as they were not taking part in a similar program. Participants were recruited from the local municipality list of LSES schools enrolling 28-35 children per class. School classes in Israel for those ages are equal to junior and senior kindergarten classes; within one school class ages can range from as young as four years to as old as seven years, although the majority of children will be in the age range of five to six years. Each school in this city had one class. In order to minimize contamination, control schools were located in different neighborhoods of the city, and their teachers were not invited to attend teacher's classes. The study received clinical trial registration: Unique Identifier: NCT01071551.

\subsection{Sample Size}

On the basis of data from an intervention conducted among similar populations, by the Association for Planning \& Development of Services for Children and Youth at Risk and their Families, 
American Jewish Joint Distribution Committee (ASHALIM-JDC) which we received by personal communication, we calculated the sample size based on the assumption that healthy packed lunch score will increase by $30 \%$. Using the software PS: Power and Sample Size Calculation software (Version 3.04.43; http://goo.gl/vC5uhf). We used $\alpha<0.05$ and $\beta=0.2$, and a ratio of 3:1 between intervention arm (IArm) and control arm (CArm). An additional 30\% was added to the sample size to account for dropouts and incomplete data. Using these criteria we enrolled in a 3:1 ratio of intervention to control, 180:60 families, giving overall 240 participants in the age range of four to seven years.

\subsection{Randomization}

After obtaining permissions from the local authorities, the Ministry of Education, and the Ethics Committee of Soroka University Medical Center (number 4712), a list of 16 schools meeting the eligibility criteria was prepared and the schools were numbered. The head of the Department of Education in the city randomly selected 11 numbers from a container for the IArm group and the remaining five schools were assigned to the CArm. The secretary then matched the numbers with the names of the schools. The randomization procedure was conducted in the presence of stakeholders and the study investigators. After randomization, all school attendees were recruited within schools that were approached sequentially. Letters were sent to families inviting them to meetings with school teachers and investigators to explain the study in detail. Mothers who agreed to participate signed an informed consent form and provided their contact details. All children participated in class activities, but information was collected only for children whose parents provided a written consent. The required sample size was achieved after recruiting four schools for the CArm and seven schools for the IArm.

\subsection{Intervention Design}

Following the ecological model for promoting children's healthy eating [12], the intervention was implemented among teachers, mothers, and children. The IArm received the full program, which included nutrition-related intervention and PA while the CArm received PA lessons only. The intervention, which lasted three months, was developed by JDC-Ashalim, the development engaged all strata of stakeholders. All the lessons were delivered by professional personnel. Structured lessons to the parents were delivered by clinical dietitians, and economists specializing in family budget planning. Physical activity sessions were delivered by physical activity teachers.

The program (Appendix A) emphasizes healthy affordable nutrition using traditional and ethnically accepted diverse nutritional recommendations. Briefly, the main themes were increasing the consumption of fruits, vegetables, and legumes; decreasing the consumption of high fat and high sugar foods; decreasing sweet beverages and promoting water drinking instead. In addition, it promoted choosing healthy snacks, preparing healthy packed lunches, choosing a healthy breakfast, preparing nutritious low-budget meals, and increasing leisure time physical activity. Mothers and children in the intervention group received structured lessons in those themes. All children in the intervention group participated in 10 weekly nutrition sessions delivered by a clinical dietitian. Each lesson was $45 \mathrm{~min}$ long, using short lectures, stories, games, and songs to cover each topic. Parents received a weekly newsletter that paralleled the information offered to the children the same week. During this 15-week period, the intervention mothers participated in three meetings, two meetings were focused on preparing nutritious meals in low budget conditions, and a meeting for children and mothers focused on the preparation of healthy breakfasts and packed lunches.

IArm teachers received specific training to enhance the intervention effects (e.g., reinforcement of key messages) and health leadership training. Teachers were trained in various ways to compliment children who brought and ate healthy packed lunches. It was impossible to omit PA from the curriculum of the control group since PA classes, is the usual care in Israeli schools. All children received an identical curriculum of 15 weekly sessions of 45 min each of PA provided by professionals. 


\subsection{Data Collection}

Data collection was performed by specially trained research assistants who were blinded to the intervention assignment. Mothers were interviewed regarding possible risk factors for childhood obesity. New immigrants from Ethiopia and the former Soviet Union were interviewed in the language of origin. Interviews were performed at baseline, at intervention termination (three months from baseline), and toward the end of the school year (six months from baseline). Interviews were structured, and included only closed ended questions. The assessors were blinded to group allocation.

\subsection{Measures}

\subsubsection{Demographics}

Information on maternal age, parity, marital status, educational level, parental smoking status, and household SES were obtained during parental interviews. The family's poverty status was defined by comparing the reported net household income per household resident to the national poverty line for families of similar size [27]. Countries of origin were grouped as follows: Israel; Europe and former USSR; Ethiopia and East Africa; and others. Maternal acculturation (the time from immigration to Israel to the interview) was divided into two categories: 0-9 years and 10+ years [28].

\subsubsection{Main Outcome Measures}

\section{Nutritional Habits}

Nutritional habits were obtained from maternal interviews. Questions were related to the variety of foods consumed, and the consumption of vegetables, sweets and candies, sugar-sweetened beverage, and water. The questions were frequency based, and were taken from a food frequency questionnaire [29].

\section{Packed Lunch Score}

As the typical Israeli school day runs from 7:30 a.m. to 2:00 p.m., children usually eat breakfast at home, packed lunches are eaten at school between 10 and 11 a.m., and then larger, hot lunches are eaten later at home. The contents of the packed lunches were evaluated without prior notification every two weeks on random days of the week and on non-intervention days to maintain blinding.

Packed lunch contents were divided into five categories: sandwiches, snacks, sweetened drinks, fruit, and vegetables following the Choices Food Profiling criteria that determine whether foods are considered a healthy option within a defined category, according to their main nutrients [30]. Food items in each category were divided into high dietary quality and low dietary quality, and received scores of 1 and 0 , respectively. The score for sandwiches was obtained by rating each of the three main ingredients separately, and then computing an average score: (1) Bread type $(0=$ white bread, $1=$ whole wheat or rye); (2) Spread ( $0=$ sweet or high fat spreads, e.g., jelly, $1=$ unsaturated fat or vegetarian spreads, e.g., avocado, humus); (3) Filling ( $0=$ foods containing saturated fat or high in sodium, e.g., salami, 1 = low-fat cheese, lean meat, and fish). All high-sugar, high-fat, and high-sodium snacks received 0 whereas low sugar breakfast cereals or low-fat yogurts received 1 . All sugar-sweetened beverages received 0 and water or milk received 1 . Any fruit or vegetable received the value 1 . If a student carried more than one food item in a category an average grade was assigned, whereas a missing food category received zero. The arithmetic sum of the points given for each food category was used as a score of packed lunch quality; scores ranged from 0 to 5 .

\section{Physical Activity and Sedentary Behaviors}

Leisure time PA of children was determined using the activity questionnaire from the Family Eating and Activity Habits Questionnaire (FEAHQ) [31]. Average daily screen time, i.e., the time 
spent by the children watching television, videos, DVDs, or playing computer games (h/week), was calculated. Usual nighttime sleeping hours were reported in the interview.

\subsection{Secondary Outcome Measures}

\subsubsection{Evaluation of Children's Nutritional Knowledge}

Children's nutritional knowledge was evaluated based on a questionnaire developed by Calfas et al. [32]. Briefly, the evaluation was performed in three stages using a progressive photo-test. First, children were presented with 19 photographs of light suppers, sandwiches, and main cooked meals, all of which depicted highly prevalent, local food items. Six options were healthy meals, 13 options were non-healthy meals, and the children were asked to define the meals as healthy or not. The second task was to choose the "healthier" meal from a pair of photographs. The third task was to grade four food photographs from the most unhealthy to the most healthy. This type of visual instrument was previously found to be appropriate for this age group in the United States and in the local population of school children in Israel [16,32]. A score (0 to 34) representing evaluation of the children's nutritional knowledge was then calculated.

\subsubsection{Anthropometric Measurements}

Mothers' and children's heights and weights were obtained in the schools using standard protocols. Children's weights were measured with a portable digital scale (Tanita HD-318; Tanita Ltd., Arlington Heights, IL 60005, USA) while barefoot and dressed in light clothing. Height was measured with a portable stadiometer (SECA-217; Seca Ltd., Hamburg, Germany). The means of two weight and height measurements were used in the analysis. Body mass index (BMI) was calculated as weight in kilograms divided by height in meters squared (weight $[\mathrm{kg}] /$ height $\left[\mathrm{m}^{2}\right]$ ). We used the growth curves of the World Health Organization (WHO) to calculate BMI z-score values according to children's age (months) and gender [33]. The World Health Organization (WHO) software AnthroPlus (Version V1.0.2; World Health Organization, Geneva, Switzerland) was used to obtain age-and sex-specific Body Mass Index (BMI-weight in kilograms divided by the square of the child's height in meters) $z$-scores for each child.

\subsection{Statistical Analysis}

To compare prevalence in categorical variables, we used the $\chi^{2}$ or Fisher's exact test. Means were compared using Student's $t$-test. Change from baseline was calculated as percent of change from baseline and its significance was estimated using Wilcoxon rank sum test. Generalized estimating equation (GEE) model was used to analyze mean changes in outcomes over time. [34] The GEE method extends standard regression analysis to also account for the correlation between clustered measurements. Three longitudinal models were used to analyze changes in outcome measures between different time-points, using identity link and exchangeable working correlation matrix. The first model was fitted to the packed lunch score, the second to the nutritional knowledge score, and the third to the BMI z-scores. In all three models, the control group was the reference group and outcome measures were continuous. The explanatory variables in the models were intervention duration (time from baseline in months), and intervention group, models were adjusted to school cluster. The BMI model was also adjusted for baseline BMI-z-score, and included screen time (h/day) as an explanatory variable. Age and sex were not included in the analyses because BMI $z$-scores were computed relative to age- and sex-specific reference growth curves. We used multiple imputation (MI) to fill in for missing data for key outcome and exposure variables. For regression analyses, parameter estimates were based on the 10 imputation models were pooled together. $p$ values $<0.05$ were considered statistically significant, 95\% Confidence Interval was calculated using the Wald Test. All the statistical analyses were performed using SPSS 18.0 for Windows (PASW Inc., Chicago, IL, USA). 


\section{Results}

\subsection{Characteristics and Adherence}

Of the 397 children attending the chosen schools, 5 did not meet the inclusion criteria; of the 392 randomized 6 refused to participate ( 3 in the IArm, and 3 in the CArm), and 6 moved away from the city ( 4 in the IArm, and 2 in the CArm); from the remaining 380 children (276 from 11 schools allocated for IArm, and 104 children from 5 schools allocated for the CArm), we sequentially recruited schools for the research (Figure 1). Parental consent to participate was obtained for 258 children. No difference was found between responders and non-responders in age, sex, and SES. Baseline data were obtained for 238 children, 231 children completed the three-month intervention, and 220 continued until the follow-up period. The overall adherence rates for completion of the program were recorded during each meeting. In the IArm $90.5 \%$ of the children attended all nutrition classes and $92 \%$ attended all PA classes. In the CArm 91\% of the children attended all PA classes. Total adherence rates for the study were $94.1 \%$ and $88.2 \%$ in the IArm and in the CArm, respectively (Figure 1). Maternal adherence to parental meetings was $84 \%$, teachers' adherence to the training program was $90 \%$. Baseline characteristics of participants are shown in Table 1. Arms were similar in most variables except for baseline BMI, BMI z-score, and mean screen time. Overweight and obesity were found in $71(29.8 \%)$ children [34]. Mothers in the I Arm were older and more physically active.

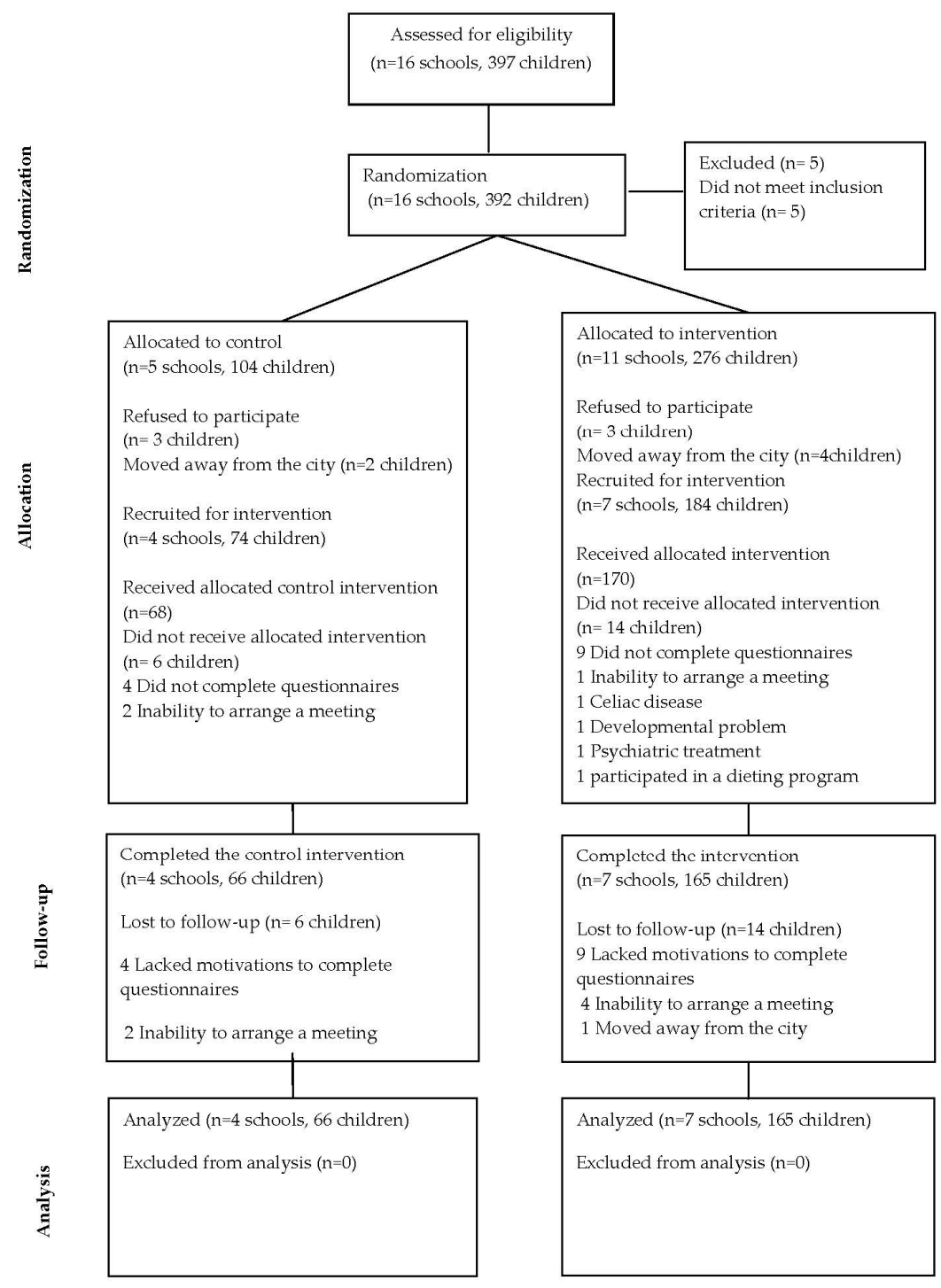

Figure 1. Flowchart of participants over the course of the study. 
Table 1. Selected baseline characteristics of the study participants by study arm $(n=238)$.

\begin{tabular}{|c|c|c|c|c|}
\hline Variable Children Preschool Classes & $\begin{array}{c}\text { All } \\
(n=238) \\
(n=11)\end{array}$ & $\begin{array}{c}\text { Control } \\
(n=68) \\
(n=4)\end{array}$ & $\begin{array}{l}\text { Intervention } \\
(n=170) \\
(n=7)\end{array}$ & $p$ Value \\
\hline Age, (mean \pm SD), months & $63.4 \pm 6.5$ & $62.6 \pm 6.9$ & $63.8 \pm 6.4$ & 0.12 \\
\hline Gender, (male/female) & $113 / 125$ & $35 / 33$ & $78 / 92$ & 0.48 \\
\hline Weight $z$-score, (mean \pm SD), $\mathrm{kg}$ & $0.3 \pm 1.3$ & $0.5 \pm 1.6$ & $0.2 \pm 1.2$ & 0.10 \\
\hline Height $z$-score, (mean $\pm \mathrm{SD}), \mathrm{cm}$ & $-0.1 \pm 1.1$ & $-0.1 \pm 1.1$ & $-0.1 \pm 1.0$ & 0.89 \\
\hline BMI z-score, (mean \pm SD) & $0.5 \pm 1.3$ & $0.9 \pm 1.6$ & $0.4 \pm 1.1$ & $0.01 *$ \\
\hline BMI, (mean \pm SD) & $16.3 \pm 2.2$ & $16.8 \pm 2.8$ & $16.0 \pm 1.9$ & $0.01 *$ \\
\hline Physical activity, (mean \pm SD), h/week & $2.4 \pm 1.2$ & $2.3 \pm 1.2$ & $2.5 \pm 1.2$ & 0.32 \\
\hline Sedentary hours, (mean \pm SD), h/day & $2.6 \pm 1.4$ & $3.0 \pm 1.7$ & $2.4 \pm 1.2$ & $0.01 *$ \\
\hline Sleeping hours, (mean $\pm \mathrm{SD})$, h/night & $9.8 \pm 1.3$ & $10.0 \pm 1.3$ & $9.8 \pm 1.3$ & 0.26 \\
\hline \multicolumn{5}{|l|}{ Family characteristics } \\
\hline Below poverty line (\%) & 32.2 & 26.9 & 34.3 & 0.28 \\
\hline $\begin{array}{l}\text { Number of siblings (\%) } \\
0-1 \\
2 \\
3+\end{array}$ & $\begin{array}{l}42.9 \\
23.5 \\
36.6\end{array}$ & $\begin{array}{l}43.5 \\
21.7 \\
34.8\end{array}$ & $\begin{array}{l}42.7 \\
24.2 \\
33.1\end{array}$ & 0.92 \\
\hline $\begin{array}{l}\text { Religiosity (\%) } \\
\text { Secular } \\
\text { Traditional } \\
\text { Orthodox }\end{array}$ & $\begin{array}{l}33.1 \\
43.3 \\
23.7\end{array}$ & $\begin{array}{l}34.8 \\
44.9 \\
20.3\end{array}$ & $\begin{array}{c}32.4 \\
42.6 \\
25\end{array}$ & 0.74 \\
\hline Current parental smoking (\%) & 58.2 & 61.2 & 57.0 & 0.56 \\
\hline Single parents (\%) & 22.6 & 21.4 & 23.0 & 0.86 \\
\hline
\end{tabular}

\subsection{Children's Eating Habits}

Changes in children's habitual nutritional habits are presented in Table 2. Significantly greater increases were shown in the intervention than in the control arm in food variety, fruit and vegetable consumption, and habitual water drinking, as well as a marked decrease in consumption of sugar-sweetened beverages (all $p<0.05$ ).

Table 2. Changes in children's nutritional habits * by study arm during a single school year.

\begin{tabular}{|c|c|c|c|}
\hline \multirow{2}{*}{ Nutritional Habit } & \multicolumn{2}{|c|}{ Intervention Group } & \multirow{2}{*}{$p$ Value $^{+}$} \\
\hline & Intervention & Control & \\
\hline$n$ & 170 & 68 & \\
\hline \multicolumn{4}{|l|}{ Eating a variety of foods } \\
\hline Baseline $n(\%)$ & $92(54.1)$ & $33(48.5)$ & 0.45 \\
\hline 3 months from baseline $n(\%)$ & $133(80.6)$ & $37(56.1)$ & \\
\hline 3 months change from baseline (\%) & 48.9 & 15.6 & $<0.001^{\mathrm{a}}$ \\
\hline 6 months from baseline $n(\%)$ & $127(79.4)$ & $34(56.6)$ & \\
\hline 6 months change from baseline (\%) & 46.7 & 16.8 & $<0.001^{a}$ \\
\hline \multicolumn{4}{|l|}{ Daily vegetables eating } \\
\hline Baseline $n(\%)$ & $96(56.5)$ & $36(52.9)$ & 0.41 \\
\hline 3 months from baseline $n(\%)$ & $134(81.2)$ & $41(62.1)$ & \\
\hline 3 months change from baseline (\%) & 43.7 & 17.4 & $0.001^{\mathrm{a}}$ \\
\hline 6 months from baseline $n(\%)$ & $126(78.8)$ & $37(61.7)$ & \\
\hline 6 months change from baseline (\%) & 39.4 & 16.5 & $0.001^{\mathrm{a}}$ \\
\hline
\end{tabular}


Table 2. Cont.

\begin{tabular}{|c|c|c|c|}
\hline \multirow{2}{*}{ Nutritional Habit } & \multicolumn{2}{|c|}{ Intervention Group } & \multirow{2}{*}{$p$ Value $^{\dagger}$} \\
\hline & Intervention & Control & \\
\hline \multicolumn{4}{|c|}{ Consume sweet and candies on a daily basis } \\
\hline Baseline $n(\%)$ & $91(53.5)$ & $33(48.5)$ & 0.23 \\
\hline 3 months from baseline $n(\%)$ & $59(35.8)$ & $20(30.3)$ & \\
\hline 3 months change from baseline $(\%)$ & -33.2 & -37.5 & 0.08 \\
\hline 6 months from baseline $n(\%)$ & $49(30.6)$ & $20(33.3)$ & \\
\hline 6 months change from baseline $(\%)$ & -42.8 & -31.3 & 0.13 \\
\hline \multicolumn{4}{|l|}{ Habitual water drinking } \\
\hline Baseline $n(\%)$ & $74(43.5)$ & $27(39.7)$ & 0.80 \\
\hline 3 months from baseline $n(\%)$ & $107(64.8)$ & $33(50.5)$ & \\
\hline 3 months change from baseline (\%) & 49.1 & 25.9 & $0.003^{b}$ \\
\hline 6 months from baseline $n(\%)$ & $100(62.5)$ & $31(51.6)$ & \\
\hline 6 months change from baseline $(\%)$ & 43.7 & 30.1 & 0.02 \\
\hline \multicolumn{4}{|c|}{ Daily consumption of sugar-sweetened beverage } \\
\hline Baseline $n(\%)$ & $79(46.5)$ & $34(50.0)$ & 0.70 \\
\hline 3 months from baseline $n(\%)$ & $45(27.3)$ & $24(36.4)$ & \\
\hline 3 months change from baseline (\%) & -41.3 & -27.2 & $0.02^{b}$ \\
\hline 6 months from baseline $n(\%)$ & $50(31.2)$ & $25(41.7)$ & \\
\hline 6 months change from baseline $(\%)$ & -32.8 & -16.6 & $0.05^{b}$ \\
\hline
\end{tabular}

* Change from baseline was calculated by subtracting the percent of change at 4 and 6 months from baseline, percent presented as percent of change. Numbers represent the number of children reported to have the habitual nutritional habit, $n=$ sample size at the specific point of time (baseline, 3 months, 6 months). ${ }^{+} p$-values for percent of change present differences between study arms that were calculated using the Wilcoxon rank sum test. ${ }^{a} p$ value $<0.001,{ }^{\mathrm{b}} p$ value $<0.05$.

\subsection{Quality of Packed Lunch}

The overall packed lunch score improved significantly over time in the IArm (Figure 2) in comparison to the CArm $(1.16 \pm 0.16,120 \%$ vs. $0.41 \pm 0.18,42 \%$, respectively, $p<0.0001)$. The overall variance explained by the model was $64 \% ; 7 \%$ of the variance in the model was accounted for by baseline BMI $z$-score, $2 \%$ of the variance by school area, $10 \%$ of the variance by time from baseline (months), $6 \%$ of the variance by intervention group, and $39 \%$ of the variance by the interaction between intervention group and months from baseline. The main contributors to the increase in quality score of the children's packed lunches were decreases in non-healthy snacks and sweet beverages and increases in fruit and vegetables; no change was found in the quality of sandwiches. The ICC for percent packed lunch score change at 3 , and 6 months was small/moderate clustering (ICCs of 0.05 , and 0.11 ).

\subsection{Physical Activity}

The mean PA time decreased significantly from baseline in the control arm compared with the intervention arm $(-0.42 \pm 0.01 \mathrm{~h}(-18.4 \%),-0.21 \pm 0.01 \mathrm{~h}(-8.4 \%)$, respectively, $p=0.03)$. Total screen time increased significantly from baseline in the control arm compared with the intervention arm $(0.54 \pm 0.02(18 \%)$ vs. no change, respectively, $p=0.001)$. No significant change was detected in mean sleeping hours in either group $(p=0.27)$. Either physical activity or sedentary behaviors did not cluster ICC $=0.00$. 


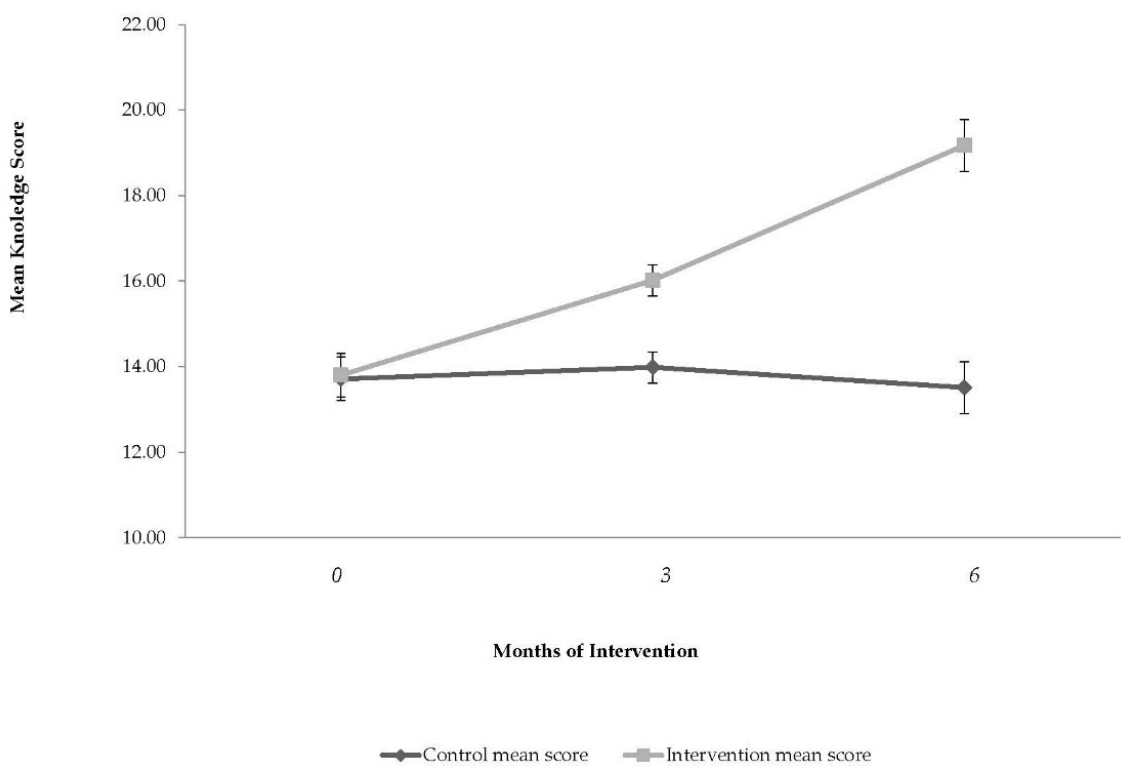

Figure 2. Changes in mean score for children's nutritional knowledge by study arm at three months and six months from baseline. Vertical bars indicate standard errors, $p$-value for intervention group, time, and interaction between time and group. To statistically evaluate the changes in children's nutritional knowledge score over time, generalized estimating equations were used, with the control group as the reference group. The explanatory variables were: time from baseline, school cluster, and intervention group.

\subsection{Children's Nutritional Knowledge}

Changes in the mean score for children's nutritional knowledge are presented in Figure 3. The baseline knowledge score was $13.8 \pm 0.5$ in the control arm and $13.7 \pm 0.6$ in the intervention arm (NS). After three and six months of intervention, the mean score in the IArm increased by $2.2 \pm 0.1$ $(16 \%)$ and $5.4 \pm 0.1(39 \%)$, respectively, compared with no change in the CArm $(p<0.001)$. The overall variance explained by the model was $49 \%, 9 \%$ of the variance in the model by baseline BMI $z$-score, $3 \%$ of the variance by school area, $7 \%$ of the variance by time from baseline (months), $4 \%$ of the variance by the intervention group, and $26 \%$ accounted for the interaction between intervention group and months from baseline. Change in nutritional knowledge score in three and six months did not cluster ICC $=0.00$.

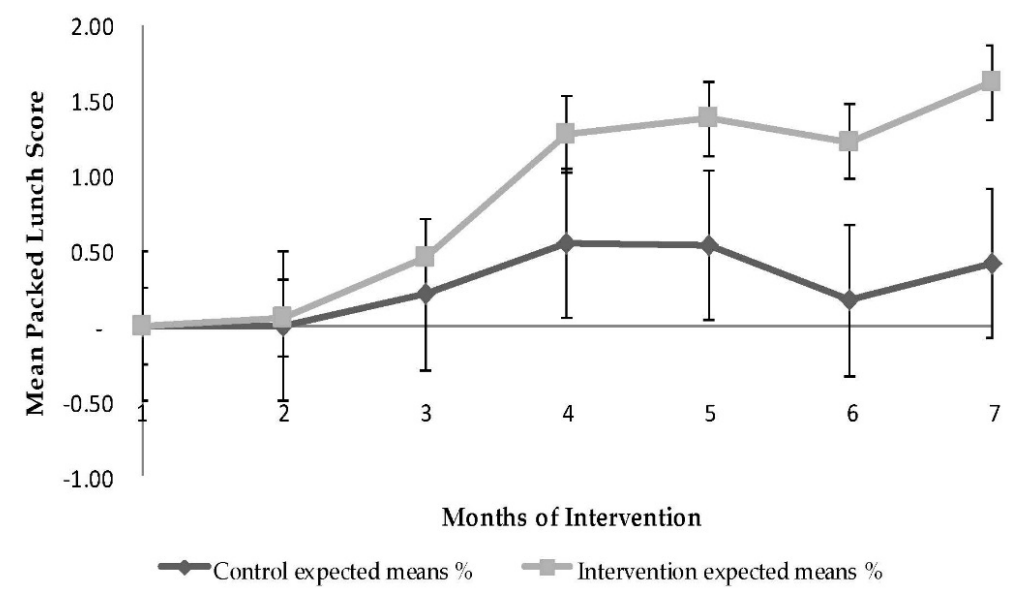

Figure 3. Changes in packed lunch score by study arm during a single school year. $p$-value was generated from the GEE model and represents $p$-values for intervention arm, time, and interaction between time and arm. Generalized estimating equations (GEE) were used to evaluate the changes in packed lunch score over time, with the control arm as the reference. Vertical bars indicate $95 \%$ CI. 


\subsection{Weight}

A significant reduction of $0.1 \mathrm{BMI} z$-score occurred in the entire study population $(p=0.003)$, in whom the BMI decreased from $16.3 \pm 2.2$ to $16.2 \pm 2.4$. The reduction was independently associated (in a GEE model) with a baseline BMI $z$-score $(\beta=0.88, p<0.001)$, with time from baseline (months) ( $\beta=-0.21, p=0.05)$, and packed lunch score $(\beta=-0.07, p=0.04)$, and an interaction between time from baseline (months) and screen-time $(\beta=0.06,95 \% \mathrm{CI}:-0.001-0.1, p=0.05)$. Total variation explained by the model was $63 \%$, baseline BMI $z$-score accounted for $20 \%$ of the variation, school area accounted for merely $0.15 \%$ of the variation, packed lunch score accounted for $15 \%$ of the variation, intervention group accounted for $2 \%$ of the variation, time accounted for $4 \%$ of the variation, screen time accounted for $3 \%$ of the variation, and the interaction between time from baseline (months) to screen time accounted for $18.85 \%$ of the variation. Change in BMI-z score in three and six months did not cluster ICC $=0.00$.

\section{Discussion}

In this RCT among LSES school aged children (four to seven years) we found that the IArm increased nutritional knowledge and enhanced positive eating habits. These results were demonstrated by the higher consumption of water, fruits, and vegetables and in a greater food variety and lower consumption of sugar-sweetened beverages compared with the CArm. Children in the IArm whose mothers attended a nutrition education intervention focused on affordable, healthy food choices, and had significant improvements in the quality of their packed lunches. Schools represent an important dietary environment in which children can consume anywhere from one-third to two-thirds of their daily caloric intake if they are enrolled in a full-day program [35]. In this study, the packed lunches prepared at home and sent with the children to their schools reflected marked changes in parental feeding behaviors. Packed lunches were targeted by two previous interventions, both of which conducted short interventions with six-week follow ups and showed increases in terms of whole grains and vegetables consumed [36,37]. A recent Cochrane review focused on children age five years or younger, identified few randomized controlled trials investigating interventions to achieve the goal of increasing fruit and vegetable consumption found in our study [14], where only one school-based intervention succeeded in increasing fruit consumption [38]. In addition, examination of the components of the packed lunch score recorded in food observations showed a decrease in intake of low nutrition value snacks and sweet drinks. The decrease in sweet drink consumption was also reported during maternal interviews. The six-month follow up showed not only that this improvement was sustained, but that it even increased in many cases. Those results suggest a benefit in enforcing school policies on the consistency of packed lunches, and the benefit of school based education programs in influencing parental feeding behaviors.

The consumption of sugar-sweetened beverages is associated with higher BMI $z$-scores among young school aged children [39]. The majority of school-based interventions among school children have reported a decrease in the consumption of sugar-sweetened beverages [21-26]. In the Munch and Move trial conducted in Australia among children at the mean age of 4.4 years, lunchbox audit showed that children in the intervention group significantly reduced sweetened drinks by 0.13 servings [39,40]. The increase in water drinking among our study population is very important, since drinking water is an effective way not only to ensure adequate hydration, but may also help reduce dietary energy density and assist in the management of body weight [41].

After adjusting for baseline BMI-z score which distributed unevenly due to cluster randomization, both study arms showed moderate weight loss. We showed a reduction of 0.1 points in BMI $z$-score in both arms, and children in the intervention arm also stabilized their screen times. Very few comprehensive interventions have been performed among young school-aged children in general and among LSES populations in particular. Most of the interventions did not show significant effects on weight reduction [14,42]. The Romp \& Chomp community intervention among preschoolers (two to five years old) showed a reduction of 0.7 percentage points in BMI $z$-scores compared with baseline 
values [26] while the first phase of the Hip-Hop to Health Jr. intervention in a minority population was effective in reducing subsequent increases in BMI in minority preschool children [43]. We believe that since both study arms received a professional PA program, their short-term success in weight loss may be due to that component of the intervention. The IArm stabilized screen time, which is a stronger predictor for increased daily energy intake than hours of physical activity, [44] may suggest a future impact on the prevention of childhood obesity [45]. Those findings reinforce the need for parental guidance on the association between children's physical activity and sedentary activity and body weight.

\section{Limitations and Strengths}

The main limitation of this study is that measurements were obtained during one school year without a long-term evaluation of the lasting impact of the intervention. However, tracking the children for another year was difficult in practice since on leaving daycare, they attend several different primary schools. While the reporting of children's nutritional habits may have been biased by the classes offered to the mothers, the reported changes, in our opinion, are supported by the independent findings of changes observed in the compositions of packed lunches.

We also limited ourselves to interviews and observations within the daycare centers, as additional measures would have greatly reduced participation. Thus, the intervention achieved high adherence rates during an entire school year among a population in which adherence rates are known to be very low. Although children's knowledge evaluation was modified from a validated tool, it was not validated amongst the study population, packed lunch score was not validated as well.

It is important to highlight that in order to benefit from such a program in a different country or culture there is a need to adapt programs performed in one country to the other.

The strengths of the study include the one-phase design, its relatively large study size, and the high adherence rates, and the economically appropriate nutritional intervention.

\section{Conclusions}

The comprehensive, school-based intervention was shown to be effective in improving eating habits, improving packed lunch quality, and stabilizing screen time of LSES school children aged four to seven years throughout a school year. The significant improvement in the quality of food brought by the children from home to class, accompanied by changes in nutritional habits, constitutes an important achievement with potential life course health implications. The trial highlights the impact of involving mothers and teachers in health promotion activities. Our results show that even a few focused economically appropriate nutrition education meetings with mothers that are supported by an ongoing educational activity of teachers and health professionals, can result in sustainable change in families' and children's nutritional knowledge, behaviors, and habits. The study reinforces the fact that either regular physical activity classes or nutrition education program and physical activity classes as part of the school curriculum, even during a short intervention time (three months), contribute to maintaining healthy body weight of school children. Further research should focus in the sustainability of healthy packed lunches, and the association between packed lunches and children's whole nutrition.

Acknowledgments: The study was funded by the following sources: (1) S\&P Foundation-Stanley Mills, Barbara Green Kay, and Jack Kay (funds received through JDC-Ashalim); (2) The S. Daniel Abraham International Center for Health and Nutrition, Ben-Gurion University of the Negev; and (3) the first author has received a personal Ph.D. fellowship grant from The Israel National Institute for Health Policy Research.

Author Contributions: V.K.-S., D.F., and D.R.S. conceived and designed the experiments; V.S., N.E., M.K., and Z.F. performed the experiments; V.K.-S., D.G., and H.V. analyzed the data; V.K.S., N.B., D.R.S., and D.F. wrote, edited, and reviewed the paper.

Conflicts of Interest: The authors declare no conflict of interest. The founding sponsors had no role in the design of the study; in the collection, analyses, or interpretation of data; in the writing of the manuscript, and in the decision to publish the results. 


\section{Abbreviations}

The following abbreviations are used in this manuscript:

\begin{tabular}{ll}
\hline MDPI & Multidisciplinary Digital Publishing Institute \\
DOAJ & Directory of open access journals \\
TLA & Three letter acronym \\
LD & linear dichroism \\
\hline
\end{tabular}

\section{Appendix A: Intervention program}

The development of the intervention engaged all strata of stakeholders: municipality representatives, a committee of stakeholders with representatives from the ministry of health, education, and the local municipality oversaw the implementation of the program. The full model focuses on LSES families emphasizing healthy diet, and physical activity. The model was focused in affordable healthy food choices.

Table A1. Children's nutrition intervention program (full intervention model) ${ }^{* *}$.

\begin{tabular}{|c|c|c|c|}
\hline Week & Objective & Themes & Specific Methods \\
\hline 1 & $\begin{array}{l}\text { Understand how the body } \\
\text { works and the importance of } \\
\text { healthy food and drinks }\end{array}$ & $\begin{array}{l}\text { The importance of healthy } \\
\text { food and drinks and active } \\
\text { lifestyle to our health }\end{array}$ & $\begin{array}{c}\text { Food samples (healthy vs. } \\
\text { non-healthy). A doll (that the } \\
\text { dietitian uses for example themes) }\end{array}$ \\
\hline \multirow{2}{*}{2} & \multirow{2}{*}{$\begin{array}{l}\text { Understand the importance } \\
\text { of water to our body }\end{array}$} & Why do we need water? & $\begin{array}{l}\text { A doll (that the dietitian uses for } \\
\text { example themes) }\end{array}$ \\
\hline & & $\begin{array}{c}\text { How do we know we drink } \\
\text { enough water? }\end{array}$ & Water and juice \\
\hline \multirow{2}{*}{3} & \multirow{2}{*}{ Fruit and vegetables } & $\begin{array}{l}\text { Vitamins and minerals in } \\
\text { fruit and vegetables }\end{array}$ & $\begin{array}{l}\text { Examples of various fruit } \\
\text { and vegetables }\end{array}$ \\
\hline & & $\begin{array}{l}\text { The importance of eating fruit } \\
\text { and vegetables of five colors }\end{array}$ & $\begin{array}{c}\text { Preparation of a vegetable salad in } \\
\text { five colors }\end{array}$ \\
\hline \multirow{3}{*}{4} & \multirow{3}{*}{$\begin{array}{l}\text { Smart choices when } \\
\text { eating sweets }\end{array}$} & What is in the sweets group? & Preparing a carrot cake \\
\hline & & $\begin{array}{l}\text { What is a portion which is } \\
\text { reasonable for a child to eat? }\end{array}$ & Examples of sweets portions \\
\hline & & $\begin{array}{l}\text { Celebrating holidays with } \\
\text { healthy/yummy food }\end{array}$ & $\begin{array}{l}\text { A doll (that the dietitian uses for } \\
\text { example themes) }\end{array}$ \\
\hline \multirow[b]{2}{*}{5} & \multirow{2}{*}{$\begin{array}{l}\text { Understand the importance } \\
\text { of eating good proteins } \\
\text { for growth }\end{array}$} & What are proteins? & Food samples \\
\hline & & $\begin{array}{l}\text { Why are proteins important } \\
\text { for us? }\end{array}$ & $\begin{array}{l}\text { A doll (that the dietitian uses for } \\
\text { example themes) }\end{array}$ \\
\hline \multirow[b]{2}{*}{6} & \multirow{2}{*}{$\begin{array}{l}\text { Understand the importance } \\
\text { of legumes for healthy } \\
\text { food choices }\end{array}$} & \multirow[b]{2}{*}{ Identifying legumes } & Cooking lentil soup \\
\hline & & & $\begin{array}{l}\text { A doll (that the dietitian uses for } \\
\text { example themes) }\end{array}$ \\
\hline 7 & Fats and oils in our food & & \\
\hline \multirow{2}{*}{8} & \multirow{2}{*}{$\begin{array}{l}\text { Ability to be make smart } \\
\text { food choices }\end{array}$} & \multirow{2}{*}{$\begin{array}{l}\text { How to help your family } \\
\text { prepare a healthy meal }\end{array}$} & Making smart choices from pictures \\
\hline & & & Preparing a fruit salad \\
\hline \multirow{3}{*}{9} & \multirow{3}{*}{$\begin{array}{l}\text { How to choose a } \\
\text { healthy sandwich }\end{array}$} & \multirow{3}{*}{ What is a healthy sandwich? } & Preparing of sample sandwiches \\
\hline & & & Choosing a sandwich from pictures \\
\hline & & & $\begin{array}{l}\text { Composing healthy sandwiches } \\
\text { from food models }\end{array}$ \\
\hline \multirow[b]{2}{*}{10} & \multirow{2}{*}{$\begin{array}{l}\text { Understanding what is a } \\
\text { healthy meal }\end{array}$} & $\begin{array}{l}\text { What contains a healthy } \\
\text { meal? Food alternatives }\end{array}$ & $\begin{array}{l}\text { Preparing a healthy meal from } \\
\text { food models }\end{array}$ \\
\hline & & $\begin{array}{l}\text { What should my body get } \\
\text { during a whole day? }\end{array}$ & $\begin{array}{l}\text { A doll (that the dietitian uses for } \\
\text { example themes) }\end{array}$ \\
\hline
\end{tabular}

** All the lessons were delivered by a clinical dietitian, each lesson was 45 min long, the topics were taught through short lectures, stories, games, and songs. Mothers received a weekly newsletter that paralleled the information offered to the children that same week. 
Table A2. School Teachers' Intervention * (full model only, $60 \mathrm{~h}$ overall).

\begin{tabular}{|c|c|c|}
\hline Week & Objective & Themes \\
\hline 1 & Introduction to health promotion & Health promotion. Health promoting schools \\
\hline 2 & Enhance teachers' motivation and health leadership & The teacher as a leader of health promoting school \\
\hline 3 & $\begin{array}{l}\text { Adopting health promotion strategies to } \\
\text { developmental stages in the life of children }\end{array}$ & Psychological development of school children \\
\hline 4 & Disease prevention & $\begin{array}{l}\text { The association between adverse lifestyle habits } \\
\text { and future diseases }\end{array}$ \\
\hline 5 & To understand the importance of breakfast & Breakfast importance \\
\hline 6 & $\begin{array}{c}\text { Enhance schoolteacher leadership by supplying } \\
\text { behavioral tools }\end{array}$ & Conflict management with mothers and children \\
\hline 7 & $\begin{array}{l}\text { How to aid developing a positive body image } \\
\text { among children }\end{array}$ & $\begin{array}{l}\text { The development of body image of children during } \\
\text { the early years of life }\end{array}$ \\
\hline 8 & $\begin{array}{l}\text { Supply the teacher with budgetary knowledge on } \\
\text { how to prepare healthy snacks, sandwiches, and } \\
\text { meals with low budgets in a culturally diverse school }\end{array}$ & Budget limitations and healthy eating \\
\hline 9 & Introduction to physical activity of young children & Physical activity skills in school aged children \\
\hline 10 & To promote hygiene in the school & Hygiene in the school \\
\hline 11 & $\begin{array}{l}\text { Experiencing physical activities adapted to } \\
\text { young children }\end{array}$ & Physical activity skills in school aged children \\
\hline 12 & $\begin{array}{l}\text { Create ordinary activities with the teacher to enhance } \\
\text { healthy school environment }\end{array}$ & Every-day life activities to promote healthy school \\
\hline \multicolumn{3}{|c|}{$\begin{array}{l}\text { * The development of the intervention engaged all strata of stakeholders: municipality representatives, a } \\
\text { committee of stakeholders with representatives from the ministry of health, education, and the local municipality } \\
\text { oversaw the implementation of the program. The full model focuses on LSES families emphasizing healthy } \\
\text { diet, and physical activity. The model was focused in affordable healthy food choices. All the lessons were } \\
\text { delivered by professional personal: Clinical psychologists, clinical dietitians, physical activity teachers, public } \\
\text { health nurses, and economists specializing in family budget planning. }\end{array}$} \\
\hline
\end{tabular}

Table A3. Mothers' intervention (full model only).

\begin{tabular}{|c|c|c|c|}
\hline Meeting Number & Children/Mothers & Themes & Specific Methods \\
\hline 1 & Mothers only & $\begin{array}{l}\text { Health food budget } \\
\text { management }\end{array}$ & $\begin{array}{l}\text { - Comparing food prices } \\
\text { - Choosing alternative food } \\
\text { items while considering } \\
\text { cultural aspects }\end{array}$ \\
\hline 2 & Mothers only & $\begin{array}{l}\text { Healthy food } \\
\text { budget } \\
\text { implementation }\end{array}$ & $\begin{array}{l}\text { - } \quad \text { Budgeting a household meal } \\
\text { - Composing a low budget } \\
\text { family menu }\end{array}$ \\
\hline 3 & Children + mothers & $\begin{array}{l}\text { Preparing healthy } \\
\text { sandwiches with a } \\
\text { reasonable budget }\end{array}$ & $\begin{array}{l}\text { - } \quad \text { Preparing healthy sandwiches } \\
\text { - Preparing individual sandwich } \\
\text { periodical tables with } \\
\text { each family }\end{array}$ \\
\hline
\end{tabular}

The development of the intervention engaged all strata of stakeholders: municipality representatives, a committee of stakeholders with representatives from the ministry of health, education, and the local municipality oversaw the implementation of the program. The full model focuses on LSES families emphasizing healthy diet, and physical activity. The model was focused in affordable healthy food choices. All the lessons were delivered by professional personal: economists specializing in family budget planning and clinical dietitians.

\section{Physical Activity Intervention Themes (children's intervention, both groups)}

Overall 15 group sessions, 45 min each, which included various activities in the school class to strengthen the child's abilities in four main domains: strength, coordination, eye-hand coordination, and flexibility. 


\section{References}

1. Wijlaars, L.P.; Johnson, L.; van Jaarsveld, C.H.; Wardle, J. Socioeconomic status and weight gain in early infancy. Int. J. Obes. (Lond.) 2011, 35, 963-970. [CrossRef] [PubMed]

2. O'Dea, J.A.; Dibley, M.J. Obesity increase among low SES Australian schoolchildren between 2000 and 2006: Time for preventive interventions to target children from low income schools? Int. J. Public Health 2010, 55, 185-192. [CrossRef] [PubMed]

3. Brauchla, M.; Juan, W.; Story, J.; Kranz, S. Sources of dietary fiber and the association of fiber intake with childhood obesity risk (in 2-18 years old) and diabetes risk of adolescents 12-18 years old: NHANES 2003-2006. J. Nutr. Metab. 2012. [CrossRef] [PubMed]

4. Johnson, L.; Mander, A.P.; Jones, L.R.; Emmett, P.M.; Jebb, S.A. Energy-dense, low-fiber, high-fat dietary pattern is associated with increased fatness in childhood. Am. J. Clin. Nutr. 2008, 87, 846-854. [PubMed]

5. Sanchez-Villegas, A.; Pimenta, A.M.; Beunza, J.J.; Guillen-Grima, F.; Toledo, E.; Martinez-Gonzalez, M.A. Childhood and young adult overweight/obesity and incidence of depression in the SUN project. Obesity 2010, 18, 1443-1448. [CrossRef] [PubMed]

6. Kalarchian, M.A.; Marcus, M.D. Psychiatric comorbidity of childhood obesity. Int. Rev. Psychiatry 2012, 24, 241-246. [CrossRef] [PubMed]

7. Fox, M.K.; Condon, E.; Briefel, R.R.; Reidy, K.C.; Deming, D.M. Food consumption patterns of young preschoolers: Are they starting off on the right path? J. Am. Diet. Assoc. 2010, 110, S52-S59. [CrossRef] [PubMed]

8. Wanders, A.J.; van den Borne, J.J.; de Graaf, C.; Hulshof, T.; Jonathan, M.C.; Kristensen, M.; Mars, M.; Schols, J.A.; Feskens, E.J.M. Effects of dietary fibre on subjective appetite, energy intake and body weight: A systematic review of randomized controlled trials. Obes. Rev. 2011, 12, 724-739. [CrossRef] [PubMed]

9. Nyaradi, A.; Li, J.; Hickling, S.; Foster, J.; Oddy, W.H. The role of nutrition in children's neurocognitive development, from pregnancy through childhood. Front. Hum. Neurosci. 2013, 7, 97. [CrossRef] [PubMed]

10. Rodenburg, G.; Oenema, A.; Kremers, S.P.; van de Mheen, D. Clustering of diet-and activity-related parenting practices: Cross-sectional findings of the INPACT study. Int. J. Behav. Nutr. Phys. Act. 2013, 10. [CrossRef] [PubMed]

11. Scaglioni, S.; Arrizza, C.; Vecchi, F.; Tedeschi, S. Determinants of children's eating behavior. Am. J. Clin. Nutr. 2011, 94, 2006S-2011S. [CrossRef] [PubMed]

12. Birch, L.L.; Davison, K.K. Family environmental factors influencing the developing behavioral controls of food intake and childhood overweight. Pediatr. Clin. North Am. 2001, 48, 893-907. [CrossRef]

13. Vereecken, C.; Maes, L. Young children's dietary habits and associations with the mothers' nutritional knowledge and attitudes. Appetite 2010, 54, 44-51. [CrossRef] [PubMed]

14. Waters, E.; de Silva-Sanigorski, A.; Hall, B.J.; Brown, T.; Campbell, K.J.; Gao, Y.; Armstrong, R.; Prosser, L.; Summerbell, C.D. Interventions for preventing obesity in children. Cochrane Database Syst. Rev. $2011,12$. [CrossRef]

15. Hu, C.; Ye, D.; Li, Y.; Huang, Y.; Li, L.; Gao, Y.; Wang, S. Evaluation of a kindergarten-based nutrition education intervention for pre-school children in China. Public Health Nutr. 2010, 13, 253-260. [CrossRef] [PubMed]

16. Nemet, D.; Geva, D.; Eliakim, A. Health promotion intervention in low socioeconomic kindergarten children. J. Pediatr. 2011, 158, 796-801. [CrossRef] [PubMed]

17. Ohly, H.; Pealing, J.; Hayter, A.K.; Pettinger, C.; Pikhart, H.; Watt, R.G.; Rees, G. Parental food involvement predicts parent and child intakes of fruits and vegetables. Appetite 2013, 69, 8-14. [CrossRef] [PubMed]

18. Gubbels, J.S.; van Assema, P.; Kremers, S.P. Physical activity, sedentary behavior, and dietary patterns among children. Curr. Nutr. Rep. 2013, 2, 105-112. [CrossRef] [PubMed]

19. Monasta, L.; Batty, G.D.; Macaluso, A.; Ronfani, L.; Lutje, V.; Bavcar, A.; van Lenthe, F.J.; Brug, J.; Cattaneo, A. Interventions for the prevention of overweight and obesity in preschool children: A systematic review of randomized controlled trials. Obes. Rev. 2011, 12, e107-e118. [CrossRef] [PubMed]

20. Olsen, N.J.; Mortensen, E.L.; Heitmann, B.L. Predisposition to obesity: Should we target those most susceptible? Curr. Obes. Rep. 2012, 1, 35-41. [CrossRef] [PubMed]

21. Dennison, B.A.; Russo, T.J.; Burdick, P.A.; Jenkins, P.L. An intervention to reduce television viewing by preschool children. Arch. Pediatr. Adolesc. Med. 2004, 158, 170-176. [CrossRef] [PubMed] 
22. Arcan, C.; Hannan, P.J.; Himes, J.H.; Fulkerson, J.A.; Rock, B.H.; Smyth, M.; Story, M. Intervention effects on kindergarten and first-grade teachers' classroom food practices and food-related beliefs in American Indian reservation schools. J. Acad. Nutr. Diet. 2013, 113, 1076-1083. [CrossRef] [PubMed]

23. Reilly, J.J.; Kelly, L.; Montgomery, C.; Williamson, A.; Fisher, A.; MCColl, J.H.; lo Conte, R.; Paton, J.Y.; Grant, S. Physical activity to prevent obesity in young children: Cluster randomised controlled trial. BMJ 2006, 333, 1041. [CrossRef] [PubMed]

24. Annesi, J.J.; Smith, A.E.; Tennant, G.A. Effects of the start for life treatment on physical activity in primarily African American preschool children of ages 3-5 years. Psychol. Health Med. 2013, 18, 300-309. [CrossRef] [PubMed]

25. Puder, J.J.; Marques-Vidal, P.; Schindler, C.; Zahner, L.; Niederer, I.; Bürgi, F.; Ebenegger, V.; Nydegger, A.; Kriemler, S. Effect of multidimensional lifestyle intervention on fitness and adiposity in predominantly migrant preschool children (Ballabeina): Cluster randomised controlled trial. BMJ 2011, 343. [CrossRef] [PubMed]

26. De Silva-Sanigorski, A.M.; Bell, A.C.; Kremer, P.; Nichols, M.; Crellin, M.; Smith, M.; Sharp, S.; de Groot, F.; Carpenter, L.; Boak, R.; et al. Reducing obesity in early childhood: Results from Romp \& Chomp, an Australian community-wide intervention program. Am. J. Clin. Nutr. 2010, 91, 831-840. [PubMed]

27. Barkali, N.; Endeweld, M.; Fruman, A.; Gottlieb, D. Poverty and Social Gaps Annual Report; National Insurance Institute: Jerusalem, Israel, 2008.

28. Portes, A. Immigration theory for a new century: Some problems and opportunities. Int. Migr. Rev. 1997, 31, 799-825. [CrossRef] [PubMed]

29. Kaufman-Shriqui, V.; Entin, A.; Fraser, D.; Novack, Y.; Bilenko, N.; Vardi, H.; Shahar, D.R. Development and validation of food frequency questionnaire for children age 5-6 using multiple methods. Int. J. Child. Health Nutr. 2013, 2, 367-376.

30. Roodenburg, A.J.; Schlatmann, A.; Dötsch-Klerk, M.; Daamen, R.; Dong, J.; Guarro, M.; Stergiou, M.; Sayed, N.; Ronoh, E.; Lansen, L.; et al. Potential effects of nutrient profiles on nutrient intakes in the Netherlands, Greece, Spain, USA, Israel, China and South-Africa. PLoS ONE 2011, 6, e14721. [CrossRef] [PubMed]

31. Golan, M.; Weizman, A. Reliability and validity of the family eating and activity habits questionnaire. Eur. J. Clin. Nutr. 1998, 52, 771-777. [CrossRef] [PubMed]

32. Calfas, K.J.; Sallis, J.F.; Nader, P.R. The development of scales to measure knowledge and preference for diet and physical activity behavior in 4- to 8-year-old children. J. Dev. Behav. Pediatr. 1991, 12, 185-190. [CrossRef] [PubMed]

33. De Onis, M.; Onyango, A.W.; Borghi, E.; Siyam, A.; Nishida, C.; Siekmann, J. Development of a WHO growth reference for school-aged children and adolescents. Bull. World Health Organ. 2007, 85, 660-667. [CrossRef] [PubMed]

34. Zeger, S.L.; Liang, K.Y.; Albert, P.S. Models for longitudinal data: A generalized estimating equation approach. Biometrics 1988, 44, 1049-1060. [CrossRef] [PubMed]

35. Briefel, R.R.; Wilson, A.; Gleason, P.M. Consumption of low-nutrient, energy-dense foods and beverages at school, home, and other locations among school lunch participants and nonparticipants. J. Am. Diet. Assoc. 2009, 109, S79-S90. [CrossRef] [PubMed]

36. Briley, M.E.; Ranjit, N.; Hoelscher, D.M.; Sweitzer, S.J.; Almansour, F.; Roberts-Gray, C. Unbundling outcomes of a multilevel intervention to increase fruit, vegetables, and whole grains parents pack for their preschool children in sack lunches. Am. J. Health Educ. 2012, 43, 135-142. [CrossRef] [PubMed]

37. Sweitzer, S.J.; Briley, M.E.; Roberts-Gray, C.; Hoelscher, D.M.; Harrist, R.B.; Staskel, D.M.; Almansour, F.D. Lunch is in the bag: Increasing fruits, vegetables, and whole grains in sack lunches of preschool-aged children. J. Am. Diet. Assoc. 2010, 110, 1058-1064. [CrossRef] [PubMed]

38. Vereecken, C.; Huybrechts, I.; van Houte, H.; Martens, V.; Wittebroodt, I.; Maes, L. Results from a dietary intervention study in preschools "beastly healthy at school". Int. J. Public Health 2009, 54, 142-149. [CrossRef] [PubMed]

39. DeBoer, M.D.; Scharf, R.J.; Demmer, R.T. Sugar-sweetened beverages and weight gain in 2- to 5-year-old children. Pediatrics 2013, 132, 413-420. [CrossRef] [PubMed]

40. Hardy, L.L.; King, L.; Kelly, B.; Farrell, L.; Howlett, S. Munch and move: Evaluation of a preschool healthy eating and movement skill program. Int. J. Behav. Nutr. Phys. Act. 2010. [CrossRef] [PubMed] 
41. Pérez-Escamilla, R.; Obbagy, J.E.; Altman, J.M.; Essery, E.V.; McGrane, M.M.; Wong, Y.P.; Spahn, J.M.; Williams, C.L. Dietary energy density and body weight in adults and children: A systematic review. J. Acad. Nutr. Diet. 2012, 112, 671-684. [CrossRef] [PubMed]

42. Fitzgibbon, M.L.; Stolley, M.R.; Schiffer, L.A.; Braunschweig, C.L.; Gomez, S.L.; van Horn, L.; Dyer, A.R. Hip-hop to health Jr. obesity prevention effectiveness trial: Postintervention results. Obesity 2011, 19, 994-1003. [CrossRef] [PubMed]

43. Fitzgibbon, M.L.; Stolley, M.R.; Schiffer, L.; van Horn, L.; KauferChristoffel, K.; Dyer, A. Two-year follow-up results for hip-hop to health Jr.: A randomized controlled trial for overweight prevention in preschool minority children. J. Pediatr. 2005, 146, 618-625. [CrossRef] [PubMed]

44. Manios, Y.; Kondaki, K.; Kourlaba, G.; Grammatikaki, E.; Birbilis, M.; Ioannou, E. Television viewing and food habits in toddlers and preschoolers in Greece: The GENESIS study. Eur. J. Pediatr. 2009, 168, 801-808. [CrossRef] [PubMed]

45. Leung, M.M.; Agaronov, A.; Grytsenko, K.; Yeh, M.C. Intervening to reduce sedentary behaviors and childhood obesity among school-age youth: A systematic review of randomized trials. J. Obes. 2012, 2012. [CrossRef] [PubMed]

(C) 2016 by the authors; licensee MDPI, Basel, Switzerland. This article is an open access article distributed under the terms and conditions of the Creative Commons Attribution (CC-BY) license (http://creativecommons.org/licenses/by/4.0/). 